Historic, archived document

Do not assume content reflects current scientific knowledge, policies, or practices. 

UNITED STATES DEPARTMENT OF AGRICULTURE

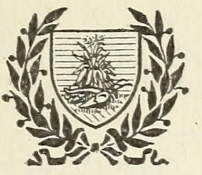

BULLETIN No. 503

Contribution from the States Relations Service

A. C. TRUE, Director

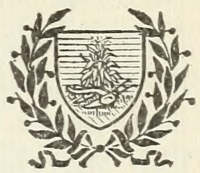

Washington, D. C.

PROFESSIONAL PAPER

March 6, 1917

\section{TURNIPS, BEETS, AND OTHER SUCCULENT ROOTS, AND THEIR USE AS FOOD.}

By C. F. Langworthy, Chief, Office of Home Economics, States Relations Service.

\section{CONTENTS.}

Page.

Page.

Introduction

Food value of succulent roots

Root vegetables less commonly known.

1

3

14
Roots used as condiments_..-- 15

Summary

\section{INTRODUCTION.}

The succulent roots, so called because water (juice) makes up so large a part of their edible substance, include such common and long-known vegetables as turnips, parsnips, radishes, carrots, salsify, beets, celeriac, onions, and garlic. In the same general group belong also a few roots which are used as condiments or spices rather than for their food value, the most common being ginger and horse-radish.

The succulent roots which are grown as garden vegetables have undoubtedly all been developed from wild forms, though, as is the case with many other plants which have been under cultivation for centuries, the wild forms of most of them are not definitely known. It can be said with certainty, however, that as they have come under cultivation the roots have increased in size, the texture has become less tough, and the flavors have been modified. Those here grouped together include such diverse forms as bulbs, roots, stalks, root-stocks, and tubers. It is evident, therefore, that from the botanist's standpoint this use of the term "roots" is not accurate; it has come into use in discussing the matter from a household standpoint doubtless

NoтE.-This bulletin is of special interest to housekeepers and to home economics extension workers, teachers, and students. It summarizes data regarding the nature, uses, and food value of succulent roots. 
for the lack of a more exact yet simple word, and is here used because of its convenience as a general descriptive term.

As a whole, "succulent roots" and "starchy roots," ${ }^{1}$ the two great groups into which edible roots are commonly divided, together constitute one of the most important sources of food.

The succulent vegetables owe their popularity in considerable measure to their good keeping qualities. After harvesting in the late autumn, they will keep in a cellar, or other cool storage place, for a long time in reasonably good condition, though as the season advances they may become somewhat tough and strong in flavor. It is a common custom in the Northern States to store such vegetables in sand rather than in bins or boxes, and some sorts, such as parsnips and oyster plant, are frequently left in the ground and dug in early spring. In the parts of the United States where the weather is mild and yet too cool to permit growth, this is an especially common method of keeping winter vegetables, for it is possible to dig them at almost any time during the winter.

Now that cold storage and improved methods of transportation have made it easily possible to secure a greater variety of vegetables at all times of the year than was formerly the case, the stored root vegetables are relatively less important. This does not mean that their use is likely to disappear, but rather that the northern markets are being supplied also with more delicate varieties; for instance, small tender beets, which many would prefer to the larger and tougher ones commonly stored for winter use. In southern markets one can obtain such vegetables fresh a good part of the year.

The usefulness of root vegetables is not limited to their underground portions, since in many cases the leaves and stems, when young and tender, are good as potherbs. Most commonly used are beet tops and turnip tops, but radish and horse-radish leaves also make good "greens," especially for mixing with greens of milder flavor, and occasionally carrot tops are also used for this purpose. The careful housekeeper who buys beets and turnips by the bunch will save and use the tops for greens. If she has a garden she will use the young plants when they are thinned out, and may also often get a dish of greens by picking tender leaves here and there from her garden bed of beets or turnips. The young green tops of onions are much used for seasoning and are also tender and palatable when cooked as a vegetable. Celeriac tops, too, are useful as a seasoning.

Most of the common succulent vegetables-turnips, beets, parsnips, carrots, etc.-are biennial plants, and if by any chance the roots re-

1 The nutritive value and uses of starchy roots have been discussed in U. S. Dept. Agr. Bul. 468 (1916). Recipes for preparing such vegetables for the table will be found in U. S. Dept. Agr. Farmers' Bul. 256 (1906). 
main in the ground and are not killed, they will start to grow and send up their flower stalks and bear seed. This is, of course, the purpose for which nature designed the reserve material stored up in the roots which we use as food. This second-year growth may be turned to advantage for the table; a surplus of turnips, too wilted for table use, may be planted out in spring and, while the leaves are still tender, will furnish a crop of good greens, or may be added to salads if one prefers.

\section{FOOD VALUE OF SUCCULENT ROOTS.}

Many factors may be considered in deciding on the food value of any material, but one which must be taken into account is its chemical composition. When that has been learned, there is a definite basis for discussing its value in supplying the protein essential as a source of nitrogen for use in tissue building and which also supplies energy, the energy-yielding starches, sugars, and fats, the tissue-building and body-regulating mineral matters, and so on. The following table presents these facts regarding the more important succulent roots:

Average composition of succulent roots, tubers, and bulbs.

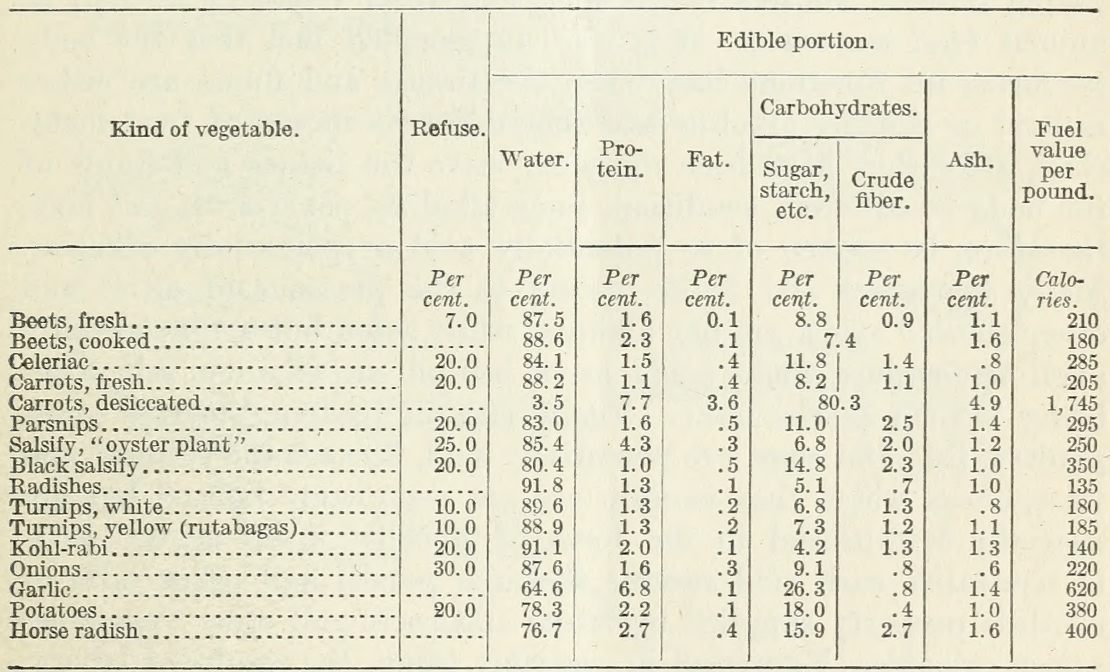

As a rule the succulent roots, tubers, and bulbs contain larger quantities of water than the starchy vegetables and consequently have a lower nutritive value, pound for pound. The proportion of nitrogenous material which they contain is low, and of this small amount not more than a third, and frequently only a fifth, is in the 
form of true protein. As regards carbohydrates, various sugars, pectose bodies, and, in some cases, pentosans, very generally constitute the reserve material which the plants store up instead of the starch, which is the principal carbohydrate in potatoes, sweet potatoes, etc. These facts are brought out clearly in figure 1, which shows the composition of common root vegetables in comparison with bread, and in figure 2, which makes a similar comparison between root vegetables, bread, and milk as sources of energy to the body. As a class these succulent roots are characterized by very marked flavors and odors, the flavor being due in part to the sugar and plant acids, and in part to the small amounts of volatile oils and similar substances which they contain and to which the odors are mainly due. Thus the peculiar flavors of turnips, radishes, onions, etc., are due chiefly to sulphur compounds.

It is not enough to consider protein and energy value in discussing: food values. Mineral substances must be taken into account also, since they are essential for body growth and maintenance and for other physiological purposes. The need for iron in making red blood (hemoglobin) and the need for lime in making bone are wellknown examples of the necessity for mineral substances. Work done in recent years has emphasized another important reason for supplying mineral matters in the diet, and from vegetable as well as animal food materials. It is now an accepted fact that the body performs its functions best when the tissues and fluids are either neutral or slightly alkaline and that different classes of food materials, after they have been digested, leave the tissues and fluids of the body in different condition, some alkaline, some acid, and may, therefore, be spoken of as potentially acid or potentially alkaline. Many vegetables and fruits, owing to the presence of citric and other similar acids, are not alkaline when eaten but are potentially alkaline, because these acids leave behind an alkaline salt after being burned in the body. Foods rich in protein, such as meat, poultry, fish, and eggs, are potentially acid, because the sulphur and phosphorus which they contain are not completely burned but are partially left behind in the form of so-called fixed acids. It is to neutralize such acid residue that the potash and other salts of alkaline property supplied by fruits and roots and other vegetables are so valuable. Expressed in everyday terms, the results of laboratory experiments show that when the diet contains such foods as meat, eggs, and fish, a generous supply of vegetable foods should be supplied also-an ample justification of the old household custom of serving potatoes, turnips, beets, and other vegetables in abundance with meat. 
SUCCULENT ROOTS AND THEIR USE AS FOOD.

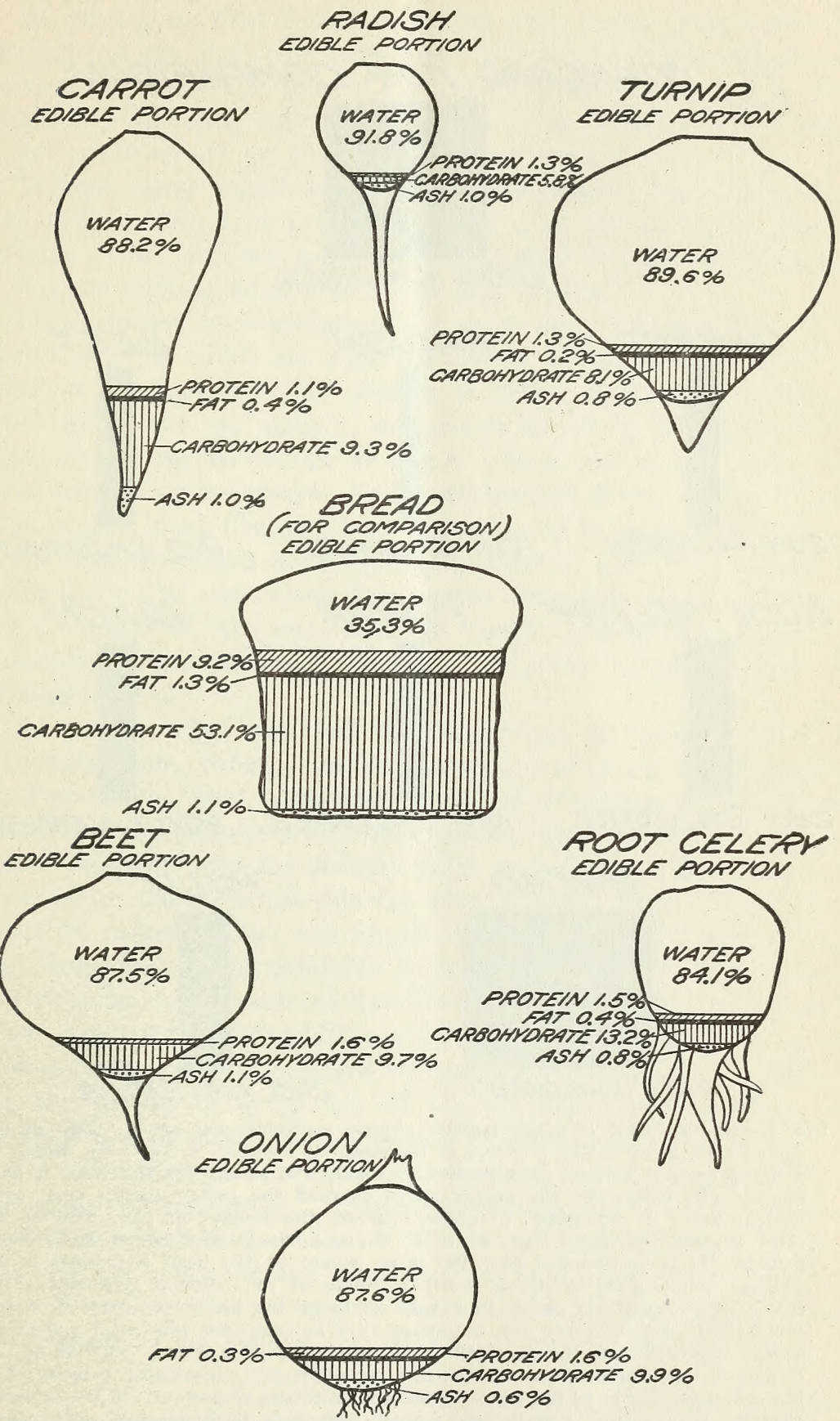

FIG. 1.-Carrot, onion, beet, and other root vegetables compared in composition with each other and with bread. 


\section{STANOAPD FOA COMPAPISON}

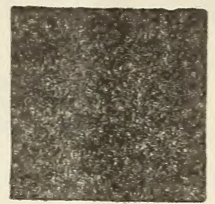

1000 CALOPIES
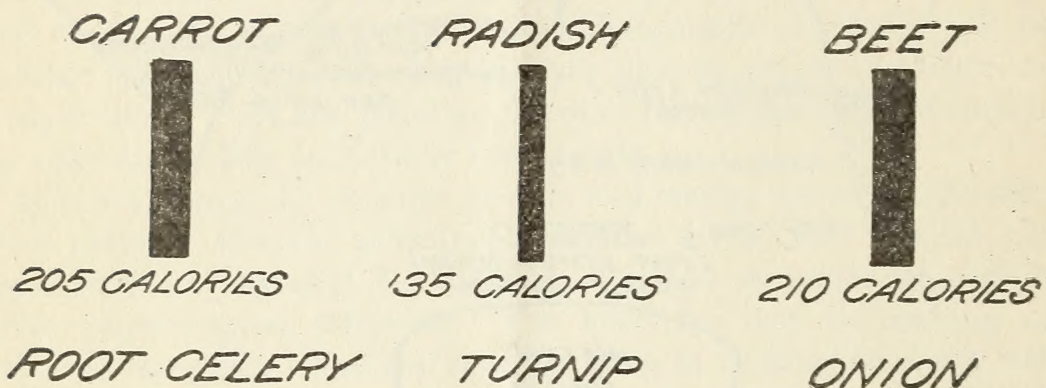

TUPNIP

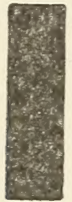

285 CALOPIES

180 CALOPIES

ONION

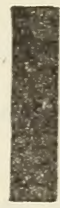

220 CALOPIES
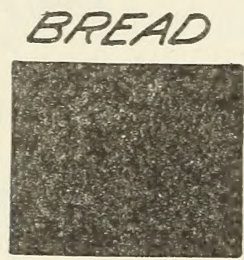

\$185 CALOPIES

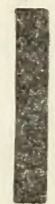

\section{CALOAIES}

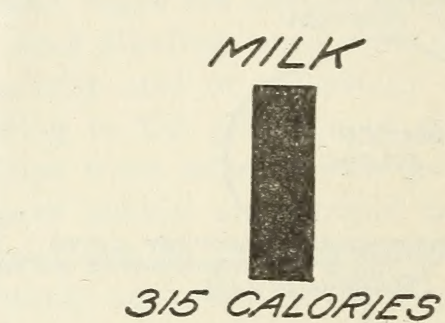

Fig. 2.-Energy value of edible portion of root vegetables per pound. Just as an engine must have fuel as a source of the power it supplies, so the body, which is a living engine, uses its food as fuel to supply the energy for the work it performs. For measuring the energy value of food the calorie is the most convenient unit. It represents in round numbers the amount of heat required to raise 1 pound of water from $0^{\circ}$ to $4^{\circ} \mathrm{F}$., and equals very nearly 3,087 footpounds. If it be assumed that the large square at the head represents 1,000 calories, the amount of energy which a pound of the different succulent vegetables would supply is shown in graphic form by the black rectangles used for comparison. These values are, in general, low as compared with such a food as bread. Nevertheless, the succulent root vegetables as a group contribute materially to the energy value of the diet in addition to furnishing material for the structural needs of the body. They are especially important for the mineral elements they supply, and in this respect rank high in comparison with other kinds of food. 
In respect to final alkalinity, beets and carrots make the best showing of the succulent roots and are superior to all our common food materials except some of the green vegetables and fruits. Parsnips and radishes outrank potatoes; while turnips, which stand below potatoes, are yet higher than sweet potatoes. ${ }^{1}$

Though many vegetables are more economical sources of protein and energy than is sometimes realized, they are probably of even greater value for their ash constituents than for the carbohydrates and other organic substances which they contain.

Furthermore, in considering the food value of vegetables, as of fruits, some of which are regarded merely as luxuries, one must not overlook the fact that they possess an actual advantage in enabling us to round out our dietary, as regards both bulk and palatability, without making the protein or energy intake excessive or compelling us to restrict the consumption of foods already in use. It can be said then, that a more liberal use of vegetables is to be encouraged; and if the cost of the diet must be strictly limited, it is often wise to restrict the use of some other food rather than this group. It should not be forgotten, however, that the cheaper vegetables are fully as valuable for the purposes mentioned as are the expensive and outof-season sorts.

To sum up what has been said regarding the food value of the succulent roots, tubers, and bulbs, they are much less important food materials, when considered from the standpoint of the protein, fat, and carbohydrates which they supply, than are the concentrated cereal foods or even the starchy roots and tubers. They are, however, very valuable in the diet for other reasons. They furnish some nutritive material, and are appetizing and generally relished, and their use often makes palatable an otherwise flavorless dish or meal. Perhaps the most important function of these roots, etc., as indeed of most of our common vegetables and fruits, is to supply the body with mineral salts which are needed for the building and repair of tissue, for the proper carrying out of the physiological functions, and particularly, to insure the alkalinity of the tissues and fluids.

Not many experiments have been made to test the digestibility of this group of vegetables. What definite technical information there is indicates that they are much like other vegetables and fruits in this respect, being neither more nor less well assimilated than they are. Thus it has been found in the case of beets that 72 per cent of the protein, 97 per cent of the carbohydrates, and 90 per cent of the total energy were utilized by the body.

${ }^{1}$ U. S. Dept. Agr., Office Expt. Stas. Buls. 185 (1907); 227 ( 910). Chemistry of Food and Nutrition. By H. C. Sherman. New York, 1911. Food Sroducts. By H. C. Sherman. New York, 1914. 
The ways in which these and other vegetables may be prepared for the table are very numerous and have been discussed in an earlier bulletin of the department. ${ }^{1}$

The various vegetables included in the table of composition have each some special characteristics which merit discussion, so the more important will be taken up separately.

\section{BEETS.}

Although the greater part of the total crop of beets is used for the production of sugar or for the feeding of farm animals, beets are used in such large quantities as a human food that they rank as one of the most common table vegetables. White or yellow table beets are occasionally seen, but the red ones are the most usual. The flavor is more delicate in the summer varieties than in the later maturing sorts. Each year the southern-grown beets are becoming more common in our winter market and are superseding the large, fully matured roots which were formerly so often stored as winter vegetables and which, late in the season, often develop a rather bitter and unpleasant flavor. It is sometimes said that beets are more nutritious than turnips, carrots, etc., but a comparison of the values for average composition given in the table (p. 3) does not substantiate this statement, all these vegetables being very much alike as regards the proportion of nutritive material present.

Cane sugar constitutes a considerable portion of the total carbohydrates of beets, as high as 10 per cent or more having been often reported. Some reducing sugar is also present. In the varieties of beets grown for sugar making the percentage of cane sugar is considerably higher, sometimes 20 per cent or more, though such high values are the exception. Beets are sometimes said to be very rich in cellulose, but this does not seem to be the case with American varieties whose average composition has been quoted. When beets are cooked, a part of the sugar and other soluble nutrients which they contain is extracted, but how much material is removed can not be stated, as no cooking experiments with beets have been found on record.

Beets are frequently canned at home for winter use, and the commercial canned article is a very well known product. The canned goods have practically the same chemical composition as freshly cooked beets. Some of the girls' canning clubs, which the State and county organizations and the United States Department of Agriculture are conducting in cooperation, have put up young beets with the tops left on, or have canned both beets and tops together-an excellent way of providing iron-rich greens in the winter diet, as kzec rops make a very palatable potherb. 
CELERIAC.

This vegetable, which is also known as turnip-rooted celery, or knob-celery, is closely related to ordinary celery, being indeed a cultured variety of the same plant grown under conditions which have developed the root rather than the stall. In Europe it is by far the most common form, but it has never been extensively cultivated in the United States, though it is found in the larger markets. The roots are white and more or less globular in shape, closely resembling turnips in appearance. As the figures in the table on page 3 show, they hare much the same general composition as the other succulent roots and tubers. Mannit, a starch-like carbohydrate, and also small amounts of asparagin, a characteristic constituent of asparagus, have been reported present in tuberous-rooted celery. This regetable has a pronounced celery flavor, due apparently to a complex oil like that in the seed, which is rather stronger or more abundant in the raw root than in the tender celery stalks. When cooked, celeriac does not differ very greatly in taste from the ordinary stewed celery. The leaves and stalks of celeriac are used for seasoning, and particularly as soup greens.

It is often said that celery is a nerve food, but there seems to be no warrant for such a statement, and the belief is probably a survival of the time when specific virtues were attributed to almost all plants and vegetables.

\section{CARROTS.}

Carrots are grown in many varieties and vary greatly in color, size, flavor, and other characteristics, those most commonly raised for the table being of medium size, deep-yellow color, tender, and of delicate flavor. Young carrots are much more satisfactory than old ones, as the latter tend to become hard and woody, especially at the core, while not infrequently the flavor of old carrots is disagreeably strong. Some varieties are more satisfactory than others for winter use, but winter carrots are, generally speaking, more used for seasoning soups and other dishes than as a table vegetable. Improved methods of transportation, storage, etc., have moreover, made the small, tender, southern-grown carrot comparatively common as a winter regetable. It is not difficult to can carrots for home use, as has been proved by the girls' canning clubs.

In composition carrots do not differ very materially from other similar roots, carbohydrates constituting the principal nutritive material. Sugar is an important constituent, 12 per cent or more being sometimes present, though perhaps 5 or 6 per cent would more nearly represent the arerage. Small amounts of pentosans have also been reported. Carrots owe their color to the presence of a yellow organic 
compound known as carotin, which has been extracted with the juice and used for coloring butter.

The water in which carrots hare been boiled is rellow in color and has a street taste, plainly shoring that some of the nutrients hare been remored in the process of cooking. Experiments hare shomn that whether the mater is hot or cold at the start makes less difference than in the case of potatoes, but the more rater used, the greater are the amounts of food materials extracted. On the other hand, the more rapidly the carrots are boiled, the smaller is the amount

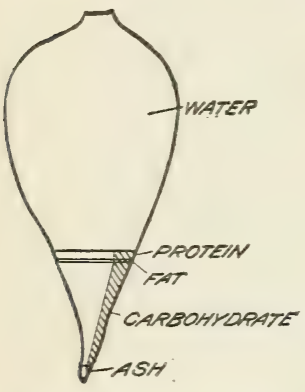

FIG. 3.-Composition and loss (shaded portion) of food material in boiling carrots. extracted. This means that quick cooking in a small quantity of water is an economical procedure. Figure 3 represents in graphic form the composition of the carrot and the loss of nutrients when boiled. Much less material is lost when the carrots are cooked by steaming. The materials extracted from the carrots in cooking consist principally of sugar or similar carbohydrates. If the water in which they or other such regetables are cooked is sared and used in soup making or in a similar way, any real loss can be aroided.

Carrots are cooked in many ways and quite generally liked. They are also much used as a seasoning regetable. Less commonly than was once the case, they are used with orange, lemon, or other flaroring in domestic jam making, carrot marmalade being an old favorite.

Dried or dessiccated carrots are on the market and are used to some extent where small bulk and good keeping qualities are important considerations. These goods resemble the fresh carrots in composition, except that they hare been concentrated by the evaporation of mater.

\section{PARSNIPS.}

Parsnips belong to the same botanical order as carrots and resemble them in form and general habit of gromth. The flesh of the root, hotrerer, is paler, being white or light-cream color, and the flaror is quite distinct and rery pronounced. Parsnips may be kept in the ground orer winter and are especially melcome additions to the diet in early spring. when regetables which hare been stored are losing their good qualities. For some reason boiled parsnips Trere long considered in some regions of Europe to be the proper regetable to serve with salt fish, but this tradition is not followed in the United States, plain boiled or fried parsnips being commonly served with roast meats of any sort. They are also used for soups, for fritters, and so on. 
As regards composition, parsnips are much like the other roots and tubers, but contain rather higher quantities of cellulose, particularly in the core, which becomes stringy and woody when the roots are old. How much of the total nutritive material is lost in boiling is not definitely known, but it is commonly thought to be considerable. The amount is doubtless affected by the same conditions as were noted with carrots.

\section{SALSIFY.}

The name "salsify" is applied to three distinct regetables; the common white salsify (Tragopogon porrifotius), known also on account of its flavor as oyster plant or vegetable oyster, black salsify (Scorzonera hispanica), the Schwarzwurzel of the German, and the so-called Spanish salsify (Scolymus hispanicus). The first of these is very commonly grown in the United States, and black salsify is also grown to a limited extent, while Spanish salsify is seldom cultivated. Both common salsify and black salsify closely resemble the other succulent roots used as food in general character. One distinction, however, is that the principal carbohydrate stored in black salsify is inulin rather than starch, and so this regetable has some reputation for use in the diet of diabetics. Since the salsifies are not injured by mild frosts, they may be left in the ground until late winter or early spring.

\section{RADISHES.}

The radishes most commonly gromn in the United States are the small ones with red exterior and white flesh, although white and dark-purple varieties and larger kinds are also well known. Though formerly red radishes were a typical spring or early-summer vegetable, they are now so commonly grown under glass that they are available all winter in large markets. To be at their best, radishes should be eaten before the roots are fully mature and should be very fresh. Besides losing their crispness, they become sweeter in taste if they are kept long after they are gathered, owing to the action of a ferment or enzym normally present which changes part of the radish starch to sugar. Similar enzyms are found in beets, carrots, etc., but in these vegetables the action is less marked.

As will be seen from the figures in the table (p. 3), young radishes contain eren more water than turnips. (See also fig. 1, p. 5.) The characteristic pungent flavor is due to organic compounds containing sulphur, similar to the essential oil in mustard. Radishes are so succulent and tender that they are doubtless well assimilated, though, as far as can be learned, their digestibility has not been studied. It is frequently said that they are productive of digestive disturbances, but such disturbances are by no means general, and when they occur 
may be due to insufficient mastication-a common occurrence in the case of succulent foods.

Besides the common radish, of which the pink or red form is the best knorn, there are larger sorts, sometimes called turnip radish, which are white or purplish in color. These are at their best in summer, but hare such good keeping qualities that they mar be held over for winter use. Though common in many American markets, these larger varieties are less well known than in parts of Europe. There is also a large variety of Japanese radish which has been grown to some extent in the United States.

Though most commonly eaten ratr, radishes, especially the larger sorts, are also cooked and served like creamed turnip, which they much resemble in flaror. The leares can be used for greens, or if they are very tender can be added to salads. The young and tender seed pods of some rarieties are sometimes used for pickling like capers; in fact, the Madras or rat-tail radish is grown exclusirely for its pods, which are cooked and also used in pickle making.

\section{TURNIPS.}

Many rarieties of turnips are gromn throughout temperate climates, some of which are coarse in texture and used as food for farm animals, while others are raised as table regetables. There is considerable variation in the color, flaror, and composition of the turnip, there being two groups commonly distinguished, one haring leares with a smooth surface and glaucous bloom and called "Swedes" or "rutabagas." Turnips are usually white-fleshed and rutabagas yellorr-fleshed, though the distinction does not always hold good. In the summer the early white varieties are usually preferred in spite of the fact that they are more watery, while in winter the yellow turnips are more commonly used. Solid as the turnip roots appear, they contain on an arerage about 89 per cent of water, or a trifle more than is found in whole milk. The total amount of nitrogenous substance is small, and only about 20 per cent of the total present is in the form of true protein. Carbohydrates are the principal nutritive material, glucose, cane sugar, pectose, pentosans, and crude fiber being the characteristic forms. The flaror of the turnip, like that of its relatives, the cabbage and the radish, is due principally to compounds of sulphur, which are so rolatile that when turnips are fed to cows these compounds pass throngh the body tissues and into the milk and gire it an unmistakable flaror. In cooking, these pungent substances are broken down to some extent and pass off into the air.

\section{KOHL-RABI.}

Kohl-rabi, or turnip-rooted cabbage, represents a curious rariety of the turnip and cabbage family in which the reserve material of the plant is stored in an abore-ground tuberlike enlargement of the 
stem just above the seed leares or cotyledons. Although, strictly speaking, it does not belong to the roots and tubers, it is so similar to them in composition, in methods of cookery, and in uses that it has been included in this discussion. Kohl-rabi is considered best in the early summer, when it is still young and tender, but it is commonly found on the market until late fall. In flavor it is more delicate than either the turnip or cabbage, though it resembles them more nearly in this respect than it does other common vegetables. Like turnip, it can be diced, cooked, and served with butter or cream sauce. It can be cooked with other vegetables with salt meat in a "boiled dinner," or sliced and used in soup as a seasoning vegetable. Kohl-rabi leaves if not too tough are excellent when cooked as greens, and may be served as a border around the kohl-rabi or as a separate dish.

ONIONS, GARLIC, AND SIMILAR VEGETABLES.

These plants are prized for use alone and for the flaror they impart to other foods, so they can be classed both with succulent roots and with those used as condiments. Onions are so frequently eaten as a vegetable that it seems logical to discuss them primarily in comparison with such materials as beets, radishes, etc.

All the members of the onion family are characterized by very strong flavor and odor, due to the presence of allyl sulphid, an oillike organic compound of sulphur. Different varieties vary somewhat in flavor and composition, and the flavor is usually more pronounced in the bulbs and roots than in the leaves or other parts, and in old than in young plants. The flaror-yielding material is very rolatile and is broken down by heat to some extent. Consequently, the cooked vegetable has a milder flavor than the raw.

In the United States the common onion in its many varieties is the best known and most used member of the onion family. The bulbs vary in size from the tiny pearl onions used for pickle making to the very large Spanish onions weighing a pound or more each. The range in color is also wide and raries from silver white, cream white, green, or yellow to red or reddish purple. The total crop produced is very large, and quantities are also imported from southern Europe, Bermuda, and the West Indies. As with most vegetables, the young and somewhat immature onions are preferred to the fully matured bulbs, though the latter have the best keeping qualities. In general, white varieties are milder in flavor than the red or yellow sorts and are generally preferred as table regetables. If they are to be kept through the winter, onions should be taken from the ground as soon as the stalks begin to wither and cured or dried in the air for about 10 days. If moist when stored they will not keep well.

The proportion of water and nutrients in onions varies greatly, not only with the variety but with the stage of growth and the 
method of storing them. Roughly speaking, the chemical composition is very similar to that of the succulent roots included in the table (p. 3). Onions contain, however, rather larger quantities of cellulose, particularly in the outer layers, which is a reason why these are usually removed before cooking. The waste in peeling and trimming onions (fig. 4) for the table may be as high as 50 per cent, but 20 or 30 per cent is perhaps a fair average. They are commonly conceded to be wholesome and have been prized since the earliest times as a valuable addition to the diet. The characteristic sulphur compound which they contain is believed to stimulate the flow of digestive juices, and this and other constitutents have a desirable effect in orercoming a tendency to constipation. As onions contain no appreciable amount of starch and little sugar, they are commonly

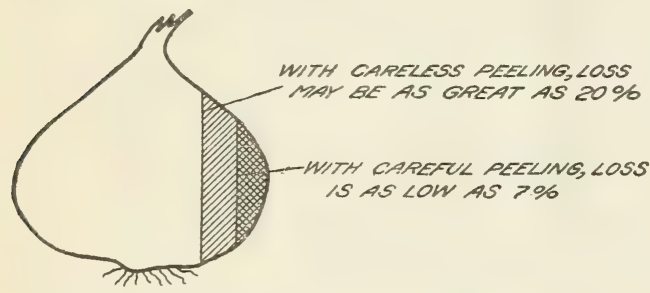

FIG. 4.- - Loss in peeling and trimming onions. allowed to invalids from whose diet starchy foods are excluded.

Garlic is a member of the onion tribe which produces a collection of small bulbs called "cloves" in the place of one large bulb. Some of the mild varieties grown in the Mecliterranean region are eaten as regetables, but in this country garlic is used mainly as a flaroring. Even so, its use is uncommon except among persons of foreign birth or food habits, and this seems unfortunate, as, rightly used, garlic may add to the palatability of salads, meats, and other dishes.

Shallot, cibol, etc., are rarieties of the onion family yielding bulbs which are much esteemed for their flaror in Europe, though they are not common in the United States. Leeks and chives, two other sorts, derelop almost no bulbs and are grown for their leares, leeks being used as a green regetable or potherb and chives mainly for seasoning. Although most families in the United States are familiar with onions. they do not generally know the similar regetables. Howerer, professional cooks consider that the other members of the group are well worth using and that some of them are almost indispensable for seasoning purposes.

As is the case with so many of the succulent root regetables, the green tops of onions and leeks are excellent cooked as greens.

\section{ROOT VEGETABLES LESS COMMONLY KNOWN.}

In other parts of the world, or in other times, many succulent roots have been used as food which, though known in the United States and grown to some extent, are seldom seen on our tables. Some of them might well be more commonly known, while others are suffi- 
ciently interesting for one reason or another to be worth at least brief mention here.

Chervil is a plant, two forms of which are common in Europe. One of them (Anthriscus cerefolium) is sometimes called street cicely and is cultivated mainly for its leares, which are used as a salad. The other, known as tuberous or turnip-rooted chervil (Chcerophyltum bulbosum), is a true root regetable. The roots are about the size and shape of small carrots and are gray or blackish on the outside, with yellow-white flesh and with a distinctive flavor. They are used in much the same way as young carrots. Seedsmen offer the seeds, but they hare never been common in the United States.

The chufa, or nut grass, or earth almond, for it is known by all of these names, is the small tuberous root of a sedgelike plant which has a flaror suggesting nuts. A natire of southern Europe, it is now cultivated in many countries. Though used as a food in a limited way, it is chiefly important as a feeding stuff. The chufa nuts are well known to children in the Southern States.

The bulbs of various lilies are eaten in the Orient and are on sale in Chinese quarters and served in Chinese restaurants in many American cities. The American Indians ate and to a small extent still use lily bulbs or corms, both roasted and raw, including the Indian cucumber (Medeola virginica), a relative of the trillium, the roots of water lilies, and many other wild roots, few of which hare been taken over into the diet of other peoples.

\section{ROOTS USED AS CONDIMENTS.}

Several roots have pronounced aromatic qualities which give them a condimental value quite independent of the nutritive material which they contain. In addition to increasing the flavor of foods, it seems possible that such condiments may stimulate the flow of digestive juices as well as please the palate. Horse-radish and ginger are the most common condimental roots, though chicory, so commonly considered in Europe a palatable addition to coffee, may also be mentioned, as well as licorice root and calamus, or sweet flag, and wild ginger, or snakeroot.

Horse-radish is a moisture-loring plant of the mustard family which is cultivated throughout north-temperate countries and is very frequently found wild in the United States, as it long ago escaped from cultivation. The root is long, rather slender, and has a sharp, peppery flaror. owing to the presence of an essential oil which much resembles in general character that in the radish and other members of the mustard family. As regards composition, horse-radish contains on an average 86.4 per cent water, 1.4 per cent protein, 0.2 per cent fat, 10.5 per cent total carbohydrates, and 1.5 
per cent ash, and has a fuel value of 225 calories per pound. Its water content is so high that it may be grouped with the succulent roots in spite of the fact that starch constitutes the principal carbohydrate present. As might be expected from the stringy character of the roots, the percentage of crude fiber is rather high. Though certain varieties of horse-radish are sometimes cooked as a regetable and it is used for seasoning pickles, for making sauces, ${ }^{1}$ to serre with meat, etc., its most common use in this country is as a condiment, when it is mixed with vinegar. It is popularly supposed that the vinegar softens the crude fiber to some extent and makes it more digestible.

Ginger, the underground rootstock of the ginger plant (Zingiber officinale), is perhaps most frequently used dry as a spice, though the fresh root or green ginger is common in autumn, being used in pickle making, preserving, and in other ways. Large quantities of ginger root are preserved in rich sugar sirup, "Canton ginger" in its round stone jars being an old-fashioned confection which is still much prized. The crystallized or candied ginger is even more common; it, like preserved ginger, is frequently served as a sweetmeat. It is also used in making desserts of various sorts ${ }^{2}$ and is generally used like candied fruits. While the nutritive value of preserved or crystallized ginger depends, of course, quite largely on the added sugar, the fresh root contains some nutritive material, the average composition being 85.6 per cent water, 1 per cent protein, 0.6 per cent fat, 11.4 per cent sugar, starch, etc., 1 per' cent crude fiber, and 1.4 per cent ash, and has a fuel value of $2 t 0$ calories per pound. Of the total fat or ether extract, about half consists of the ethereal oil which, together with a pungent, nonvolatile constituent called gingerol, gives to ginger its characteristic flavor. The young and tender ends of the branching root, or rhizome, called ginger buds, are the most delicate portion as regards both texture and flavor.

Calamus, or flagroot, is found wild in Europe, as well as in the United States, and has long been known for its pungent and aromatic flavor. The root is most often gathered, though the young blossom portion is also eaten and has a specially mild flavor. Flagroot was used for a seasoning in earlier times in England and in the United States also, where it is still used to a limited extent like candied citron to flavor stewed fruit and so on, though its use at the present time is rery largely limited to the candied flagroot which housekeepers often make at home and which is also a commercial product.

${ }^{1}$ U. S. Dept. Agr., Farmers' Bul. 391 (1910), p. 27. [Recipe for making horse-radish sauce.]

${ }^{2}$ U. S. Dept. Agr., Yearbook 1912, pp. 505-552. Raisins, Figs, and Other Dried Fruits and Their Use. 
Wild ginger (Asarum canadense), or the snakeroot of our northern woods, may also be mentioned. The spicy, aromatic root of this plant was gathered quite commonly in earlier times and dried, being used like many other wild plants in domestic medicine. Its use as a condiment was also common, a bit of the dried root being carried about and nibbled at odd times in the same way as calamus and dried orris root. In pioneer cookery it occasionally took the place of some more common spice, and does now, the fresh root being used to some extent like true ginger in pickle making. It also can be candied.

Laboratory tests have shown that both flagroot and wild ginger root used in cookery in small quantities in place of other spices give a distinctive flavor which many would consider pleasant.

Another native American root-sassafras-which has some importance for condimental purposes, may be mentioned here. The bark of the root yields a flavoring extract more used in confectionery making than in the home. However, it is interesting to know that tea made from this root, which was once so common a beverage under the name of "saloop," is still used to some extent in parts of the United States, both in the home and commercially.

\section{SUMMARY.}

The plants which store their reserve material in underground roots, tubers, and bulbs have, in many instances, come to be regarded by man as among the most important foodstuffs. Cultivation has to a great extent modified the size, structure, flavor, and appearance of the parts which are eaten, and the garden varieties are as a rule superior to the wild in these respects and show important modifications in the season of growth and in other ways. As a class the edible roots, tubers, and bulbs may be divided into the following groups: (1) Starch-yielding vegetables, as potatoes, sweet potatoes, dasheens, etc.; (2) succulent roots, as beets, carrots, and parsnips; and (3) condimental or flavoring roots, as horse-radish and ginger.

The edible roots, tubers, and bulbs have a high water content and are valued as additions to the diet for their appetizing, succulent qualities and the bulk which they give, as well as for the nutritive material which they supply. Starch is the material most commonly stored in the underground receptacles, though it is replaced in some plants by closely related bodies such as inulin, mannin, etc., by sugars of different sorts, pectoses, or other carbohydrates. The proportion of nitrogenous material in such foodstuffs is small, and true albumin seldom constitutes more than a third of the total protein. The proportion of fat is also small, being composed in some cases very largely of wax-like bodies found in the skin, or of coloring matter; and in other cases, of volatile oils and similar sub- 
stances, which give the plants their characteristic flavor and odor. Mineral matter is an important constituent of these vegetable foods, the proportion, though small, being about the same as is found in many other common articles of diet. Sodium, potassium, iron, sulphur, and phosphorus compounds are the common mineral constituents. As the mineral matters exist in combination with organic acids and other bodies, they contribute materially to the flavor of the tubers, roots, etc.

Beets, carrots, parsnips, salsify, turnips; and onions are the most common of the so-called succulent root crops used as food. They differ from starch-yielding vegetables like potatoes mainly in containing a larger proportion of water, 85 to 90 per cent on an average, and consequently a smaller proportion of nutritive material. Furthermore, it is generally true that starch is not the characteristic carbohydrate of these vegetables, its place being taken by sugars of different sorts, pectose bodies, and other similar carbohydrates, while the percentage of crude fiber is also rather higher than in the edible starch-yielding roots and tubers. Many of the vegetables included in this group are characterized by marked flavors and odors due to the presence of volatile organic sulphur compounds in their juices. In the members of the onion tribe these are especially strong, and some varieties are used almost exclusively as flavoring materials, while other and milder sorts are also used in large quantities as table vegetables.

Though not very nutritious in proportion to their bulk, root crops as a class offer some advantages over most other vegetable foods. They are so easily grown and so productive that under ordinary conditions they sell at prices within the reach of all. Many of them may be kept over winter in such good condition that they are practically never out of season, or are in season when other vegetables are scarce. The carbohydrates, the principal nutritive material present, are in forms which are readily and well assimilated. The characteristic flavor which some of these vegetables possess is a decided advantage, as it makes the vegetables palatable and adds to the variety of the diet. Succulent vegetables of all sorts contribute bulk to the diet and so are valuable from the standpoint of hygiene, because within limits bulkiness is a favorable condition for normal digestion and also of importance in overcoming a tendency to constipation. They are among the important sources of necessary mineral matters in the ordinary diet. Since the body performs its functions best if its tissues and fluids are either neutral or slightly alkaline, and since vegetables tend to produce that effect, they have a special value as regulators of the body processes. 


\section{PUBLICATIONS OF THE DEPARTMENT OF AGRICULTURE OF INTEREST IN CONNECTION WITH THIS BULLETIN.}

\section{AVAILABLE FOR FREE DISTRIBUTION BY THE DEPARTMENT OF AGRICULTURE.}

Potatoes, Sweet Potatoes, and Other Starchy Roots as Food. (Department Bulletin 468.)

Principles of Nutrition and Nutritive Value of Food. (Farmers' Bulletin 142.)

Preparation of Vegetables for the Table. (Farmers' Bulletin 256.)

Potatoes and Other Root Crops as Food. (Farmers' Bulletin 295.)

Care of Food in the Home. (Farmers' Bulletin 375.)

Storing and Marketing Sweet Potatoes. (Farmers' Bulletin 548.)

FOR SALE BY THE SUPERINTENDENT OF DOCUMENTS, GOVERNMENT PRINTING OFFICE, WASHINGTON, D. C.

Extension Course in Vegetable Foods. (Department Bulletin 123.) Price, 10 cents.

Cassava. (Farmers' Bulletin 167.) Price, 5 cents.

Losses in Boiling Vegetables and Composition and Digestibility of Potatoes and Eggs. (Office of Experiment Stations Bulletin 43.) Price, 5 cents.

Course in Use and Preparation of Vegetable Foods for Movable and Correspondence Schools of Agriculture. (Office of Experiment Stations Bulletin 245.) Price, 10 cents.

\section{ADDITIONAL COPIES}

OF THIS PUBLICATION MAY BE PROCURED FROM

THE SUPERTNTENDENT OF DOCUMENTS

GOVERNMENT PRINTING OFEICE

WASHINGTON, D. C.

$A T$

5 CENTS PER COPY

$\nabla$ 
